\title{
Hebben we genoeg zorg?
}

Citation for published version (APA):

Groot, W. N. J. (1998). Hebben we genoeg zorg? Maastricht University. https://doi.org/10.26481/spe.19980619wg

Document status and date:

Published: 19/06/1998

DOI:

$10.26481 / \mathrm{spe} .19980619 \mathrm{wg}$

Document Version:

Publisher's PDF, also known as Version of record

\section{Please check the document version of this publication:}

- A submitted manuscript is the version of the article upon submission and before peer-review. There can be important differences between the submitted version and the official published version of record.

People interested in the research are advised to contact the author for the final version of the publication, or visit the DOI to the publisher's website.

- The final author version and the galley proof are versions of the publication after peer review.

- The final published version features the final layout of the paper including the volume, issue and page numbers.

Link to publication

\footnotetext{
General rights rights.

- You may freely distribute the URL identifying the publication in the public portal. please follow below link for the End User Agreement:

www.umlib.nl/taverne-license

Take down policy

If you believe that this document breaches copyright please contact us at:

repository@maastrichtuniversity.nl

providing details and we will investigate your claim.
}

Copyright and moral rights for the publications made accessible in the public portal are retained by the authors and/or other copyright owners and it is a condition of accessing publications that users recognise and abide by the legal requirements associated with these

- Users may download and print one copy of any publication from the public portal for the purpose of private study or research.

- You may not further distribute the material or use it for any profit-making activity or commercial gain

If the publication is distributed under the terms of Article $25 \mathrm{fa}$ of the Dutch Copyright Act, indicated by the "Taverne" license above, 


\section{Universiteitsbibliotheek}

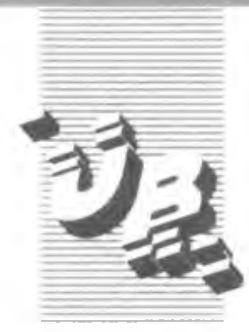

De uitleentermijn verstrijkt op:

\section{OKT. 1998}

\section{MEI 4999}

Universiteit Maastricht

Postbus 616

6200 MD Maastricht

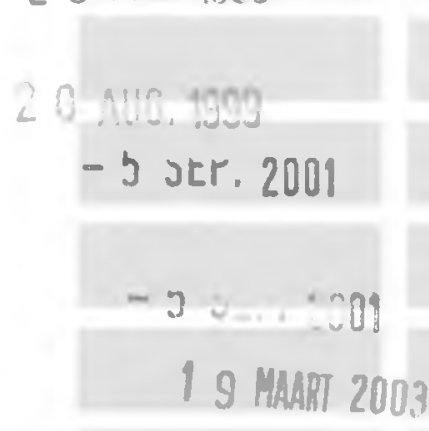

Gelieve deze publicatie tijdig te retourneren of (telefonisch) verlenging van de uitleentermijn aan te vragen.

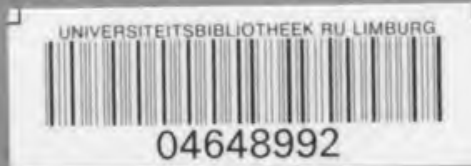




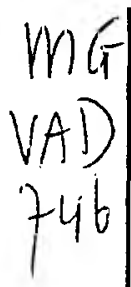

\title{
HEBBEN WE GENOEG ZORG?
}

\author{
Openbare Rede
}

bij de Aanvaarding van het Ambt van Hoogleraar Gezondheidseconomie, aan de Universiteit Maastricht op vrijdag 19 juni 1998

door

Wim Groot 


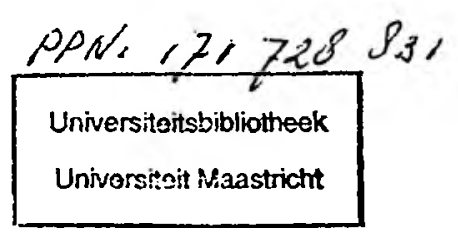


Mijnheer de Rector Magnificus,

Zeer geachte Dames en Heren,

Economische argumenten nemen in de discussie over de gezondheidszorg een steeds belangrijker plaats in. Dit komt onder meer tot uitdrukking in maatregelen om te komen tot meer marktwerking in de gezondheidszorg en in de pogingen om de doelmatigheid van de gezondheidszorg (verder) te verbeteren. Naarmate economische overwegingen een belangrijker rol gaan spelen in de gezondheidszorg, neemt het belang van de gezondheidseconomie als wetenschappelijke discipline toe.

De markt voor gezondheidszorg verschilt van de meeste andere markten. Een reden hiervoor is dat het goed 'gezondheid' niet - zoals andere goederen - kan worden verhandeld op de markt. Een andere reden is dat de vraag naar gezondheidszorg voor een belangrijk deel wordt bepaald door de gezondheidstoestand van een individu. De gezondheidstoestand is voor een deel stochastisch en niet te voorzien. Vanwege de onzekerheid over de gezondheidstoestand in de toekomst ontstaat er een verzekeringsmarkt voor de kosten van gezondheidszorg. Naast vragers van zorg (consumenten) en aanbieders van zorg (zorginstellingen) is er dus nog een derde partij op deze markt: de verzekeraars.

De welvaartstheorie levert het instrumentarium voor economen om de relaties tussen de agenten op de markt van de gezondheidszorg te evalueren. De twee criteria voor evaluatie zijn: doelmatigheid en rechtvaardigheid. Bij rechtvaardigheid gaat het vooral om problemen ten aanzien 
van de toegankelijkheid van zorg (in het bijzonder voor consumenten met een laag inkomen of een chronische ziekte). In de woorden van de Minister van Volksgezondheid, Welzijn en Sport: "The balancing act of the Health Ministry is aimed at realizing a fair distribution of resources and an increase of efficiency and effectiveness of health services, while maintaining broad access to essential services of high quality" (Borst-Eilers 1997, p. 15). Op grond van rechtvaardigheidsoverwegingen is er bij ziektekostenverzekeringen sprake van risicosolidariteit en inkomenssolidariteit. Vanuit een economische invalshoek valt er over de doelmatigheidsaspecten van de gezondheidszorg echter meer te zeggen dan over de rechtvaardigheidsaspecten.

Zelfs als er sprake is van een mogelijkheid voor wederzijds voordelige ruil tussen partijen, zal een optimaal niveau van transacties op de markt voor gezondheidszorg niet altijd worden gerealiseerd. Er zijn verschillende oorzaken voor inefficiënties (of marktfalen) op de markt voor gezondheidszorg. De meest bekende hiervan is het probleem van moral hazard in de relatie tussen consument en verzekeraar. Twee soorten moral hazard in de gezondheidszorg kunnen worden onderscheiden. Ten eerste kan een verzekering tegen ziektekosten er toe leiden dat individuen minder aandacht schenken aan (en dus minder kosten maken voor) preventieve maatregelen tegen ziekten. Ten tweede kan een verzekering er toe leiden dat bij ziekte meer middelen dan noodzakelijk worden besteed aan gezondheidszorg, omdat de kosten door de verzekering worden gedekt. Moral hazard leidt dus tot inefficiënties in de consumptie van gezondheidszorg. 
In de relatie tussen verzekeraar en aanbieders van zorg is er sprake van een afruil efficiëntie in productie (dat wil zeggen, behandeling van medische problemen tegen de laagst mogelijke kosten, gegeven de kwaliteit van zorg) en adverse selection. ${ }^{1}$ Adverse selection - het verschijnsel dat alleen mensen die verwachten dat de opbrengst van een verzekering hoger is dan de kosten, zich verzekeren - is een tweede mogelijke oorzaak van marktfalen in de gezondheidszorg.

Tenslotte kan er in de relatie tussen consument en de aanbieder van zorg gewezen worden op problemen die betrekking hebben op informatie over de kwaliteit van de aangeboden zorg. Patiënten kunnen de kwaliteit van aanbieders van zorg (b.v. de kwaliteit van dokters) niet altijd goed inschatten. Aanbieders van zorg weten ook niet altijd precies wat de goede of de beste behandeling is. Aangezien de aanbieders zowel adviseren als zorgdiensten aanbieden, leidt dit tot een principal-agent probleem: de arts (de 'agent') neemt beslissingen in het belang van de patiënt (de 'principal'), maar laat bij deze beslissingen ook het eigenbelang meewegen. Het verschijnsel dat het aanbod van zorg zijn eigen vraag oproept (supplier-induced demand) is hiervan een gevolg (zie Arrow 1963 en Stano 1987).

Uit het voorgaande blijkt dat in elk van de relaties tussen de drie partijen - consumenten, aanbieders van zorg en verzekeraars - er problemen van marktfalen zijn als gevolg van onvolledige informatie of a-symmetrische informatie (Akerlof 1970). Maar niet alleen in de onderlinge

' Voor een uitgebreid overzicht van deze literatuur, zie Newhouse 1996. 
relaties speelt onvolledige informatie een rol. In Phelps (1992) wordt bijvoorbeeld een beschrijving gegeven van de gevolgen van onzekerheid in de kennis over de werkzaamheid van medische interventies onder zorgaanbieders.

Er zijn naast onvolledige informatie nog andere redenen aan te geven voor het bestaan van marktimperfecties in de gezondheidszorg. Externe effecten bijvoorbeeld. Veel goederen hebben gezondheidsbevorderende kenmerken of zijn juist een risico voor de gezondheid. En soms beide. Mensen doen aan sportbeoefening omdat ze het een leuke sociale activiteit vinden. Daarnaast leidt actieve sportbeoefening aan de ene kant tot verbetering van de conditie, maar doet het aan de andere kant de kans op letsel in de vorm van blessures toenemen. Verder zijn er natuurlijk externe effecten verbonden aan overdraagbare ziekten. Evenals onvolledige informatie vormen ook externe effecten een reden voor overheidsinterventie. Onder andere middels accijnzen op tabak, subsidies voor sport, inentingscampagnes en voorlichting tegen (seksueel) overdraagbare ziekten. Het merit-good motief speelt hierbij ook vaak een rol: de overheid meent beter te weten wat goed is voor haar burgers.

Een vierde reden voor marktfalen in de gezondheidszorg is gelegen in problemen die te maken hebben met onvolledige concurrentie in het aanbod van zorg. De structuur van de markt van de aanbod van zorg verschilt van de meeste andere produktmarkten. Zo zijn de meeste zorgaanbieders georganiseerd in de vorm van non-profit instellingen. De doelstellingen en (institutionele) restricties van non-profit 
organisaties verschillen van die van profit organisaties (zie Pauly 1987 voor een overzicht van deze verschillen). De institutionele verschillen kunnen leiden tot verschillen in de efficiëntie van de productie van zorg. Sommige studies uitgevoerd in de Verenigde Staten vinden verschillen in gedrag - ten aanzien van toegang tot zorg, kwaliteit van de zorg, kostenefficiëntie en de mate van opportunistisch gedrag ten opzichte van consumenten die over minder informatie beschikken - tussen 'profit' en 'non-profit' organisaties in de gezondheidszorg. In andere studies worden echter geen verschillen gevonden (voor een overzicht, zie Gray 1986).

Er is meestal geen sprake van volledige concurrentie in het aanbod van zorg. Op veel terreinen kan de marktvorm worden beschreven als een van monopolistische concurrentie. Met name de regionale spreiding van zorginstellingen leidt tot productverschillen in de zorgsector. De organisatie en het management van zorgsinstellingen heeft ook invloed op de doelmatigheid van het functioneren. Belangrijke aspecten hierbij zijn of zorgverleners in loondienst zijn bij de instelling en de bijbehorende vraag of zorgverleners per verrichting worden betaald of via een abonnementssysteem.

Samenvattend: er zijn verschillende redenen aan te geven voor marktfalen in de gezondheidszorg, variërend van moral hazard en adverse selection tot het functioneren van de markt voor zorgaanbod. Met name moral hazard problemen leiden er toe dat de kosten van de gezondheidszorg hoger zijn dan noodzakelijk. 
Als er geen marktfalen zou zijn en de markt voor gezondheidszorg perfect zou werken, zou veel van de bestaansgrond aan de gezondheidseconomie als wetenschapsdiscipline ontvallen: veel van de onderwerpen waarmee de gezondheidseconomie zich bezighoudt zijn terug te voeren op problemen van marktfalen in de gezondheidszorg. Problemen van marktfalen uiten zich niet alleen in de vorm van sterk stijgende kosten voor de gezondheidszorg, wachtlijsten en andere maatschappelijke knelpunten, maar ook in de vorm van vragen over de kwaliteit en de effectiviteit van zorg. In hoeverre de gezondheidseconomie aan de oplossing van deze (maatschappelijke) problemen een bijdrage kan leveren, hoop ik in de volgende paragraaf aan de geven.

\section{De maatschappelijke bijdrage van de gezond- heidseconomie}

De kosten van de gezondheidszorg stijgen. Tussen 1985 en 1995 namen de uitgaven voor de gezondheidszorg toe van $7,9 \%$ tot $8,8 \%$ van het bruto binnenlands product (CBS 1997). Naar verwachting zullen ook in de toekomst de kosten van de gezondheidszorg blijven stijgen. Er kunnen drie factoren worden onderscheiden die voor deze kostenstijgingen verantwoordelijk zijn: de vervanging van bestaande verrichtingen door nieuwe en duurdere procedures, een stijging van de prijs van bestaande producten in de gezondheidszorg en een toename van het gebruik van voorzieningen in de gezondheidszorg. Met name op deze laatste factor wil ik nader ingaan. Volgens een recent rapport van de WRR 
(1997) zal vooral onder invloed van door demografische veranderingen en veranderingen in de levensstijl de vraag naar zorg verder toenemen.

Het vraagstuk van de kostenstijgingen in de gezondheidszorg staat sterk in de belangstelling. Twee vragen zijn hierbij van belang. Ten eerste gaat het om de vraag in welke mate de samenleving bereid is te betalen voor de steeds verder toenemende mogelijkheden die de medische wetenschap biedt. Sommigen beweren dat het uitgebreide stelsel van ziektekostenverzekeringen heeft geleid tot te snelle groei van de medische technologie en de daarbij behorende kostenstijging (Weisbrod 1991 en Newhouse 1992). Het is echter zeer wel mogelijk dat individuen bereid zijn om te betalen voor deze technologische groei. Vanuit economisch gezichtspunt is een tweede belangrijke maatschappelijke vraag of de kosten voor de gezondheidszorg hoger zijn dan noodzakelijk (dat wil zeggen, of de gezondheidszorg doelmatig werkt).

Ik wil nu wat nader ingaan op de eerste vraag, te weten: wat hebben we over voor de gezondheidszorg? Een aspect van deze vraag is die naar de behoefte aan zorg. Hoeveel gezondheidszorg hebben we nodig? Is de toename van het gebruik van de gezondheidszorg een teken dat we meer behoefte hebben aan zorg? 


\section{Veranderingen in het gebruik van voorzie- ningen in de gezondheidszorg ${ }^{2}$}

Uit gegevens van het Centraal Bureau voor de Statistiek (CBS 1994, 1997) - over het gebruik van medische voorzieningen in de periode 1985-1995 - blijkt dat in elk geval een deel van de kostenstijging in de gezondheidszorg toegeschreven kan worden aan de toename van het gebruik van medische voorzieningen. Tussen 1981 en 1995 nam het percentage Nederlanders dat per jaar een bezoek aan de huisarts brengt toe van $69 \%$ tot $76 \%$ : een toename van iets meer dan $10 \%$ in minder dan 15 jaar tijd. Gedurende dezelfde periode steeg het percentage dat een medisch specialist bezocht van $36 \%$ tot $39 \%$ en verdubbelde het bezoek aan een fysiotherapeut van $7 \%$ tot $14 \%$. Alleen het percentage dat opgenomen is geweest in een ziekenhuis bleef in deze periode nagenoeg gelijk: ongeveer $7 \%$ van de bevolking verblijft per jaar een dag of langer in het ziekenhuis (uitgezonderd vrouwen die voor een bevalling naar het ziekenhuis gaan).

De vraag is nu: waarom is het gebruik van medische voorzieningen gestegen? Globaal zijn op deze vraag twee antwoorden mogelijk. Ten eerste is het mogelijk dat er een toename is geweest in het aandeel van personen met kenmerken die het waarschijnlijker maken dat gebruik wordt gemaakt van medische voorzieningen. Hierbij kunnen we op de eerste plaats denken aan demografische ontwikkelingen, zoals de vergrijzing. Ouderen maken meer gebruik van de gezondheidszorg dan jongeren. Door de vergrijzing zal dus

${ }^{2}$ Een uitgebreidere versie van het onderzoek dat hier beschreven wordt, is te vinden in Groot (1998). 
het relatieve gebruik toenemen. Daarnaast kunnen we denken aan ontwikkelingen op de arbeidsmarkt, de ontwikkeling van het menselijk kapitaal en de algehele inkomens- en welvaartsstijging. $\mathrm{Bij}$ de arbeidsmarktontwikkelingen vallen vooral de toename van de participatiegraad van vrouwen en de daling van de werkloosheid op. Mogelijk dat de toename van de arbeidsdeelname van vrouwen leidt tot meer problemen in de combinatie van betaalde arbeid en zorgtaken. Dit kan zich uiten in meer gezondheidsklachten. De daling van de werkloosheid zal waarschijnlijk eerder leiden tot minder gebruik van de gezondheidszorg, aangezien bekend is dat werklozen meer dan gemiddeld met gezondheidsklachten kampen. De toename van het menselijk kapitaal komt tot uitdrukking in de stijging van het opleidingsniveau van de bevolking. Als hoger opgeleiden gezonder leven, leidt dit tot minder gebruik van gezondheidszorg. Daarentegen zijn hoger opgeleiden mondiger en stappen ze wellicht eerder naar een arts. De inkomens- en welvaartsstijging leidt ook tot meer gebruik van gezondheidszorg, als de goederen en diensten van de gezondheidszorg een normaal goed zijn.

De andere mogelijke verklaring voor de toename in het gebruik is niet dat de bevolking zodanig is veranderd dat het gebruik toeneemt, maar dat de geneigdheid om gebruik te maken is gestegen. Waar men vroeger met een kwaal of ongemak bleef doorlopen, stapt men tegenwoordig wellicht eerder naar een arts.

Voor de analyses van de veranderingen in medische consumptie zijn de 1987 en 1995-golven van het Aanvullend Voorzieningengebruikonderzoek (AVO) van het Sociaal en Cultureel Planbureau gebruikt. Voor een uitgebreidere beschrijving van de gebruikte gegevens en de econometrische methoden, zie Groot (1998). 
De data bevatten informatie over vier typen van medische dienstverlening, te weten de huisarts, medisch specialist, de fysiotherapeut en het ziekenhuis. De enquêtevragen zijn als volgt geformuleerd:

- Heeft U de afgelopen 3 maanden de huisarts geraadpleegd?

- $\quad$ Heeft $U$ gedurende de afgelopen 3 maanden contact gehad met een specialist?

- $\quad$ Heeft U gedurende de afgelopen 12 maanden gebruik gemaakt van een fysiotherapeut?

- Bent U de afgelopen 12 maanden opgenomen geweest in een ziekenhuis of kliniek?

De cijfers van het AVO bevestigen het eerder geschetste beeld dat het bezoek aan de huisarts, de medisch specialist en de fysiotherapeut significant is toegenomen tussen 1987 en 1995, terwijl het aandeel van de bevolking dat is opgenomen in het ziekenhuis constant is gebleven. Dit geldt zowel voor ziekenfonds verzekerden als voor particulier verzekerden. De toename in het grootst voor de huisarts. Het bezoek aan de huisarts steeg tussen 1987 en 1995 onder ziekenfonds verzekerden met $35 \%$ en onder particulier verzekerden met $43 \%$.

Een tweede conclusie die kan worden getrokken is dat er significante verschillen zijn in het gebruik van huisarts, fysiotherapeut en ziekenhuis tussen ziekenfonds en particulier verzekerden. In alle drie de gevallen is het gebruik onder ziekenfonds verzekerden hoger dan onder particulier verzekerden.

Een derde conclusie is dat de toename in het gebruik groter is geweest onder particulier verzekerden dan onder ziekenfonds verzekerden. Onder particulier verzekerden is het bezoek aan een huisarts toegenomen met $43 \%$, aan een medisch specialist met $39 \%$ en aan een fysiotherapeut met 
$29 \%$. Onder ziekenfonds verzekerden was deze stijging respectievelijk $35 \%, 32 \%$ en $24 \%$.

Als we kijken naar het gebruik van medische voorzieningen naar geslacht en aard van de ziektekostenverzekering in 1995, dan blijkt dat zowel onder ziekenfonds als onder particulier verzekerden de medische consumptie significant hoger is onder vrouwen dan onder mannen. Dit geldt voor alle vier de voorzieningen die worden onderscheiden.

De verschillen tussen ziekenfonds en particulier verzekerden zijn minder eenduidig. Onder mannen is het bezoek aan een huisarts, fysiotherapeut en ziekenhuis hoger onder ziekenfonds verzekerden dan onder particulier verzekerden. Het verschil is relatief het grootst voor ziekenhuisopnamen: van de mannen die via een ziekenfonds zijn verzekerd is $9,5 \%$ in de afgelopen 12 maanden opgenomen geweest in een ziekenhuis. Van de particulier verzekerde mannen is dit maar 7\%. Er zijn geen significante verschillen in het gebruik van een medisch specialist tussen ziekenfonds en particulier verzekerde mannen.

Onder vrouwen is er alleen een significant verschil in ziekenhuisopnamen tussen ziekenfonds en particulier verzekerden. Van de vrouwen in het ziekenfonds is $12,3 \%$ in de afgelopen 12 maanden opgenomen geweest. Onder particulier verzekerde vrouwen is dit maar $9,7 \%$.

Uit de uitkomsten van de decompositie analyse van de veranderingen in het gebruik van medische voorzieningen tussen 1987 en 1995 blijkt dat het grootste deel van de stijging in deze periode kan worden verklaard uit een verandering in de neiging om van een huisarts gebruik te maken. Dezelfde conclusies kunnen worden getrokken voor alle andere groepen. Dat wil zeggen: voor vrouwen, voor perso- 
nen met een particuliere ziektekostenverzekering en voor het gebruik van de overige drie medische voorzieningen. Dus, ongeacht het geslacht, de aard van de ziektekostenverzekering en de aard van de medische voorziening kan de toename in het gebruik van de voorzieningen in de gezondheidszorg voornamelijk worden toegeschreven aan een verandering in de geneigdheid om van deze voorzieningen gebruik te maken en niet zozeer aan een verandering in de karakteristieken van de populatie in de periode 1987-1995.

Voor een oordeel over de gewenste omvang van de gezondheidszorg is het van belang te weten waarom het gebruik van medische voorzieningen stijgt? De meest opvallende conclusie uit het zo juist besproken onderzoek is dat - in tegenstelling tot wat vaak wordt gedacht - de toename van het gebruik van voorzieningen in de gezondheidszorg niet kan worden toegeschreven aan de vergrijzing of aan andere demografische of maatschappelijke ontwikkelingen, maar voornamelijk het gevolg is van veranderingen in de geneigdheid van individuen om gebruik te maken van medische voorzieningen. Veranderingen in populatiekenmerken die de kans op gebruik vergroten - zoals demografische veranderingen - spelen slechts een geringe rol in de toename van het gebruik van de gezondheidszorg.

Hoe zou de toename van de neiging om van medische voorzieningen gebruik te maken, kunnen worden verklaard? Een studie van Kosa \& Robertson (1975) laat zien dat slechts $40 \%$ van de mensen die zich ziek voelt medische hulp zoekt. Het is mogelijk dat het percentage dat bij ziekte medische hulp zoekt de afgelopen jaren is gestegen. Dit zou verklaren waarom de geneigdheid om van medische zorg gebruik te maken is gestegen. 
De toename van het gebruik en de kosten van de gezondheidszorg roept onvermijdelijk de vraag op hoeveel (collectieve) middelen we willen uitgeven voor gezondheidszorg. Is dat $8 \%$ van het nationaal inkomen zoals 10 jaar geleden, $9 \%$ van het nationaal inkomen zoals nu, of misschien nog wel meer? Of geven we juist meer uit aan gezondheidszorg dan we eigenlijk zouden willen?

Een bijbehorende vraag is: hoe willen we dat het budget voor de gezondheidszorg wordt verdeeld? In de gezondheidszorg kan een onderscheid worden gemaakt tussen de curatieve voorzieningen (behandeling door een arts) en de verzorgende en verplegende voorzieningen. Hoeveel belang wordt gehecht aan 'cure' versus 'care'? Binnen de curatieve voorzieningen kunnen daarnaast een groot aantal behandelingen worden onderscheiden. Ook in de verpleging en de verzorging kunnen vele vormen worden onderscheiden. Voor een goed begrip zou voor elk van deze vormen van behandeling, verpleging en verzorging moeten worden nagegaan hoeveel we ervoor overhebben. Dit te bepalen zou een zeer omvangrijke inspanning vergen. Daarom beperk ik me hieronder bij het beantwoorden van de vraag naar de gewenste omvang van zorg tot een vorm van behandeling, namelijk die voor hart- en vaatziekten.

\section{Hoeveel hebben we over voor de gezondheids- zorg?}

In het eerdergenoemde WRR (1997) rapport wordt betwijfeld of de samenleving ook in de toekomst nog wel bereid 
zal blijken te zijn om de toenemende kosten in de gezondheidszorg te blijven betalen. Over de daadwerkelijke bereidheid om te betalen voor gezondheidszorg is weinig bekend. Inzicht hierin zou zeer van belang zijn voor de maatschappelijke discussie over de kosten van de gezondheidszorg. Hiermee zou ook de vraag kunnen worden beantwoord welke medische verrichtingen binnen een pakket van collectieve ziektekostenverzekeringen thuishoren en voor welke risico's individuen zelf een beslissing moeten nemen of ze die willen verzekeren of niet. Kortom, de vraag of de pil, het kunstgebit, de toxal behandelingen, open hartoperaties in het buitenland en de alternatieve geneeswijzen in het ziekenfondspakket horen of niet.

Zoals in het eerder genoemde WRR rapport terecht wordt geconstateerd, worden beslissingen over uitbreidingen van het collectieve pakket van gezondheidszorg zonder een vaste systematiek en dus op vrij willekeurige gronden genomen. Politici besluiten vaak ad hoc en onder druk van belangengroepen over opname van een voorziening in het basispakket van de gezondheidszorg. $\mathrm{Er}$ is geen systematisch beleid over de vraag welke gezondheidsrisico's in het pakket van collectieve ziektekostenverzekering thuishoren en welke niet. In het verleden zijn hiervoor verschillende voorstellen gedaan - waarvan de 'trechter van Dunning' nog de meest bekende is - maar deze hebben geen van alle veel resultaat gehad. ${ }^{3}$

Een veelgebruikte methode om de bijdrage van verschillende voorzieningen aan de volksgezondheid te

3 Commissie Keuzen in de Zorg (Commissie Dunning), Kiezen en Delen, Staatsuitgeverij, Den Haag 1991. 
meten is die van de Quality Adjusted Life Years (QALY's). In deze methode wordt het aantal gewonnen levensjaren door medische verrichtingen berekend, gecorrigeerd voor de winst in de kwaliteit van leven door de interventie. Het is een manier om in één maat zowel effecten op levensverlenging als gezondheidsverbetering mee te wegen. Met deze maat kunnen interventies die gezondheidswinst opleveren - ofwel door ziekte te voorkomen of te genezen, ofwel door de sterfte of beperkingen ten gevolge van ziekte of aandoeningen te vermijden of te verminderen - met elkaar worden vergeleken. Een kosten-effectiviteitsratio kan dan worden uitgedrukt in QALY's per gulden. Zo kan bijvoorbeeld worden berekend dat de kosten-effectiviteitsratio van de behandeling van leukemie $f 20.000$ per QALY bedraagt en de behandeling van borstkanker ongeveer $f 6.000$ per QALY. Dat wil zeggen de kosten voor een gewonnen levensjaar zijn twintigduizend gulden bij leukemie en zesduizend gulden bij borstkanker. Bij eenzelfde gezondheidswinst (QALY) is behandeling van borstkanker dus goedkoper dan behandeling van leukemie. De WRR stelt voor om de verdeling van de collectieve middelen voor gezondheidszorg te bepalen op grond van een kosten-effectiviteitsratio. ${ }^{4} \mathrm{De}$ medische interventies met de laagste kosten per QALY komen dan eerder in aanmerking voor financiering dan de verrichtingen met hoge kosten per QALY. Als deze eenduidige methode wordt gehanteerd, dan kan veel willekeur in de collectieve financiering van medische handelingen worden voorkomen.

${ }^{4}$ De WRR geeft daarbij de voorkeur aan een variant op de QALY, de Disability Adjusted Life Year methode of DALY's. 
Het gebruik van deze methode vereist echter dat wordt aangegeven waar de grens ligt van wat nog wel wordt gefinancierd en wat niet. Als bijvoorbeeld de grens wordt getrokken bij $f 10.000$ per QALY, dan komt behandeling voor borstkanker wel in aanmerking voor financiering, maar behandeling voor leukemie niet. Moet de grens dus hoger liggen, of juist lager? Helaas kan met behulp van een kosteneffectiviteitsratio niet aangegeven worden waar de grens moet liggen. Zonder het met zoveel woorden te zeggen, gaat de WRR er van uit dat de collectieve middelen voor de gezondheidszorg vastliggen en dat de kosten-effectiviteitsmaatstaf alleen wordt gebruikt om tot een systematische verdeling van dit budget te komen. De omvang van het budget bepaalt dan wat de grens is voor wat nog collectief wordt gefinancierd. Echter, zowel een te hoge grens als een te lage grens kan ongewenst zijn. Een te hoge grens leidt er toe dat medische handelingen worden gefinancierd die maatschappelijk gezien niet efficiënt zijn. Een te lage grens kan tot gevolg hebben dat sociaal verantwoorde handelingen niet worden verricht. Zonder aan te geven waar de grens voor bekostiging moet liggen, heeft het weinig zin kosteneffectiviteitsafwegingen te maken.

Een consequente doorvoering van dit beleid vereist dat ook de stap van een kosten-effectiviteitsafweging naar een kosten-baten analyse wordt gemaakt. Hierbij wordt niet alleen gekeken naar de kosten per QALY, maar ook naar de baten van deze gezondheidswinst.

De laatste jaren is enig onderzoek gedaan naar de waarde die individuen hechten aan een extra levensjaar. Hierbij kunnen twee benaderingen worden onderscheiden. In de eerste worden individuen direct gevraagd hoeveel geld ze over hebben om een bepaald gezondheidsrisico uit te sluiten (bijvoorbeeld hoeveel geld heeft $u$ over als de kans op kan- 
ker zou worden gehalveerd?). Aan deze methode kleven veel bezwaren. Individuen kunnen vaak gezondheidsrisico's niet goed inschatten (wat is de kans dat een gezonde man/vrouw van 35 jaar kanker krijgt?). Verder hoeft het bedrag dat mensen zeggen bereid te zijn over te hebben voor een hypothetische daling van het gezondheidsrisico niet overeen te komen met het bedrag dat men werkelijk bereid is te betalen. Meestal wordt dan ook de voorkeur gegeven aan de tweede methode, waarbij wordt gekeken hoeveel geld individuen daadwerkelijk moet worden geboden om ze te bewegen een baan of een activiteit met een bepaald gezondheidsrisico te accepteren. Zo wordt bijvoorbeeld gekeken naar het extra loon dat mijnwerkers verdienen ten opzichte van vergelijkbare andere werknemers. Dit bedrag wordt gezien als de extra compensatie die werknemers moet worden geboden, om de risico's die aan het werken in mijnen verbonden zijn, te accepteren. Ook aan deze methode kleven echter bezwaren. Ten eerste is het de vraag of de uitkomsten die zijn verkregen voor een bepaalde groep (laag opgeleide mannelijke werknemers in de mijnbouw) in een bepaalde beroepsgroep kunnen worden gegeneraliseerd tot de gehele bevolking. Ten tweede is er het probleem van zelf-selectie: personen die kiezen voor een beroep als mijnwerker zijn niet een willekeurige groep uit de samenleving maar een zichzelf selecterende groep van mensen voor wie de risico's van het werken in mijnen relatief minder zwaar wegen dan voor de rest van de beroepsbevolking.

Samen met Henriëtte Maassen van den Brink en Erik Plug heb ik een eenvoudige methode ontwikkeld om de waarde die individuen hechten aan een bepaalde gezondheidswinst te bepalen. Deze methode is gebaseerd op de inkomenswaarderingsmethode, ontwikkeld door B.M.S. van 
Praag. ${ }^{5}$ We gebruiken de inkomenswaarderingsmethode om de compensatie te berekenen die mensen met hart- en vaatziekten nodig hebben om eenzelfde welvaartsniveau te bereiken als gezonde personen. Met behulp van informatie over de verwachte levensduurverlenging bij uitschakeling van hart- en vaatziekten kan vervolgens de waarde van het leven worden bepaald. Ik wou de belangrijkste uitkomsten van dit onderzoek hier kort bespreken ${ }^{6}$.

De inkomenswaarderingsmethode

De inkomenswaarderingsmethode meet de waardering van het inkomen en is gebaseerd op de volgende vraag die aan respondenten wordt voorgelegd: "Welk inkomen is voor $\mathrm{U}$ in Uw situatie een zeer goed inkomen; een goed inkomen; een voldoende inkomen; een onvoldoende inkomen; een slecht inkomen; een zeer slecht inkomen?". Als twee respondenten hun inkomen in de inkomenswaarderingsvraag een gelijke verbale kwalificatie toekennen, dan genieten zij hetzelfde niveau van welvaart. Wij merken daarbij op dat een gelijke waardering van inkomen geen gelijkheid van inkomen impliceert. Aangezien de inkomenswaarderingsvraag verwijst naar de situatie waarin de respondent zich bevindt, is de welvaartsfunctie gemeten conditioneel op de kenmerken van het individu. In het bijzonder blijkt het inkomen dat als goed, voldoende, etc. wordt aangemerkt,

${ }^{5}$ Deze methode vindt zijn oorsprong in het proefschrift van B.M.S van Praag uit 1968 en is onder andere verder ontwikkeld in A. Kapteyn \& B.M.S. van Praag (1973).

${ }^{6}$ Het vervolg van deze paragraaf is gebaseerd op Groot, Maassen van den Brink \& Plug (1998). 
afhankelijk te zijn van het feitelijke huishoudinkomen, de omvang van het huishouden, het opleidingsniveau en van de leeftijd van de respondent. Voor ons onderzoek voegen we naast deze genoemde variabelen er nog één toe, namelijk of de respondent lijdt aan hart- en vaatziekten.

De gegevens over de inkomenswaardering, hart- en vaatziekten, inkomen, etc. zijn, evenals die in het vorige onderzoek, ontleend aan het Aanvullend voorzieningengebruikonderzoek 1995 (AVO 1995) van het Sociaal en Cultureel Planbureau. In het onderzoek zijn alle personen van 18 jaar en ouder genomen.

De compensatie voor een goede gezondheid

Een slechte gezondheid hoeft niet alleen van invloed te zijn op welvaart, maar kan ook gevolgen hebben voor het inkomen. Gezondheid beïnvloedt de verdiencapaciteit, bijvoorbeeld doordat een slechte gezondheid de inzetbaarheid op de arbeidsmarkt en de carrièremogelijkheden beperkt. Ongezonde mensen zullen vaker arbeidsongeschikt zijn en een uitkering hebben. Gezondheid heeft dan dus zowel direct als indirect - via het inkomen - invloed op de welvaart. Om met dit indirecte effect rekening te houden, zijn eerst de determinanten van het inkomen bepaald. Hart- en vaatziekten hebben zoals verwacht een negatief effect op het inkomen. Er kan worden berekend dat iemand van 30 jaar met hart- en vaatziekten ongeveer $33 \%$ minder verdient dan iemand van deze leeftijd zonder hart- en vaatziekten. Op 50jarige leeftijd is het verschil $16 \%$ en op 70 -jarige leeftijd is het verschil $6 \%$.

De variabele 'Hart- en vaatziekten' in de welvaartsvergelijking geeft een indruk van het verlies in kwaliteit van leven als gevolg van het gezondheidsprobleem. De verslechtering van de gezondheid is niet alleen van invloed op de 
kwaliteit van leven, maar ook op de kwantiteit of de levensverwachting. Het verlies in kwaliteit van leven door hart- en vaatziekten is groter voor iemand van 30 jaar dan voor iemand van 70 jaar. De invloed van gezondheidsproblemen op welvaart varieert dus naar verwachting met de leeftijd.

Hart- en vaatziekten verlagen het welvaartsniveau van het individu en leiden er toe dat er meer inkomen nodig is om eenzelfde niveau van welvaart te bereiken. Hoeveel meer iemand met hart- en vaatziekten nodig heeft dan iemand zonder hartklachten wordt duidelijk uit enkele aanvullende berekeningen. Een 25-jarige met hartklachten moet $85,7 \%$ meer inkomen hebben dan eenzelfde persoon zonder klachten om eenzelfde welvaartsniveau te hebben. Bijna tweederde deel van het totale effect voor een 25 -jarige is het gevolg van de geringere verdiencapaciteit. Het extra benodigde inkomen voor personen met hartklachten om eenzelfde welvaartsniveau te bereiken als iemand zonder klachten neemt af met de leeftijd.

De uitkomsten laten zien dat voor alle leeftijden geldt dat hart- en vaatziekten leiden tot een lager inkomen en door dit lager inkomen tot een lager welvaartsniveau. Dit indirecte welvaartseffect is tot het 65-ste jaar kleiner dan het directe welvaartsverlies door hartklachten. Voor mensen ouder dan 65 jaar is het directe welvaartseffect kleiner dan het indirecte effect.

De genoemde percentages kunnen ook worden omgerekend naar geldbedragen. In dat geval berekenen we het bedrag dat mensen met hartklachten moet worden geboden om een even hoge welvaart te hebben als mensen zonder hartklachten. Dit kan ook worden gezien als het bedrag dat mensen over hebben om de nadelen van hartklachten af te kopen. Hierbij dient te worden bedacht dat hart- en vaatziekten twee gevol- 
gen heeft: de kwaliteit van leven neemt af en de levensverwachting daalt. $\mathrm{Bij}$ volledige uitschakeling van hart- en vaatziekten neemt de levensverwachting voor mensen die lijden aan deze ziekte jonger dan 65 jaar met 11 tot 13 jaar toe. Voor personen ouder dan 65 jaar is de winst in levensverwachting 6 tot 9 jaar. Verder is de toename in de levensverwachting, als het sterfterisico voor deze klachten volledig wordt uitgeschakeld, voor mannen met hart- en vaatziekten groter dan voor vrouwen. ${ }^{7}$ Met behulp van deze gegevens berekenen we de compenserende variatie van hart- en vaatziekten.

Het bedrag dat mensen bereid zijn te betalen om de nadelige gevolgen op de kwaliteit van leven en de levensverwachting te elimineren, hangt af van het gekozen welvaartsniveau. Het bedrag is ook hoger voor jongeren dan voor ouderen en hoger voor mannen dan voor vrouwen. Dit komt voornamelijk doordat de winst in levensverwachting door eliminatie van de sterftekans door hart- en vaatziekten voor mannen groter is dan voor vrouwen en groter voor jonge mensen dan voor oudere. Bij een welvaartsniveau dat als 'zeer goed' wordt omschreven, is een man van 25 jaar bereid om ruim eenmiljoennegenenzeventigduizend gulden te betalen voor de eliminatie van de gevolgen van hart- en vaatziekten. Voor een vrouw van deze leeftijd is dit bedrag negenhonderddrieduizend gulden. Op 55 jarige leeftijd zijn deze bedragen voor mannen en vrouwen, respectievelijk negenhonderdvijfenzeventigduizend gulden en achthonderdnegenenzestig duizend gulden. Als uitgegaan wordt van een voldoende

7 Deze cijfers zijn ontleend aan J. van Ginneken, A. Bannenberg \& A. Dissevelt (1989). 
welvaartsniveau, dan zijn deze bedragen meer dan de helft lager.

Deze cijfers geven aan hoeveel mensen moeten worden gecompenseerd voor het verminderde aantal verwachte levensjaren en de geringere kwaliteit van leven door hart- en vaatziekten. Op basis van deze bedragen kan worden berekend welke waarde individuen aan de totale levensduur hechten. Hiervoor hebben we informatie nodig over de verwachte levensduur. De levensverwachting bedraagt in Nederland ongeveer 74 jaar voor mannen en 80 jaar voor vrouwen. Met behulp hiervan is de waarde van het leven tussen 18 en 74 jaar voor mannen en 18 en 80 jaar voor vrouwen berekend. We rekenen vanaf het 18-de levensjaar, omdat personen jonger dan 18 jaar buiten het onderzoek zijn gelaten.

De waarde van het leven blijkt voor vrouwen hoger dan voor mannen. Dit komt omdat de levensverwachting van vrouwen hoger is dan voor mannen. Uitgaande van een zeer goed welvaartsniveau is de waarde van het leven voor vrouwen bijna 5 miljoen gulden. Voor mannen is het viermiljoenvierhonderdveertigduizend gulden.

De conclusie van deze analyse is dat mensen een aanzienlijk bedrag moet worden geboden om hun te compenseren voor het gezondheidsrisico van hart- en vaatziekten. Uitgaande van een voldoende welvaartsniveau moeten mensen ongeveer vierhonderdduizend gulden worden geboden ter compensatie van het risico van hart- en vaatziekten. Als een zeer goed welvaartsniveau als uitgangspunt wordt genomen, ligt dit bedrag tussen negenhonderdduizend en een miljoen gulden. Omgerekend komt dit neer op een bedrag tussen dertigduizend en vijfentachtigduizend gulden per gewonnen levensjaar door uitschakeling van hart- en vaatziekten. Dit is 
meer dan de kosten per gewonnen levensjaar van de meeste behandelingsmethoden bij hart- en vaatziekten. Zo bedragen de kosten per gewonnen levensjaar van een open-harttransplantatie vijfentwintig- tot vijfenzestigduizend gulden en de kosten van een by-pass operatie tussen vijf- en vijfenvijftigduizend gulden per gewonnen levensjaar (zie Adang 1997). Deze verrichtingen zijn dus vanuit een oogpunt van doelmatigheid te rechtvaardigen.

\section{Tot besluit}

Mijnheer de Rector, Dames en Heren,

Zoals ik heb aangegeven, kunnen veel problemen waarmee de gezondheidszorg te maken heeft, worden herleid tot problemen van marktfalen. De analyse van marktfalen in de gezondheidszorg leidt tot de vraag of de kosten voor de gezondheidszorg hoger zijn dan noodzakelijk. Een belangrijke oorzaak van marktfalen in de gezondheidszorg is dat er geen mechanismen zijn om te bepalen hoeveel wij bereid zijn te betalen voor gezondheidszorg. Het is deze, naar mijn mening fundamentele vraag, die ik hier vanmiddag heb willen stellen. Het is, met andere woorden, de vraag: Hebben wij genoeg zorg?

De toename van het gebruik van voorzieningen in de gezondheidszorg lijkt er op te wijzen dat de behoefte aan zorg nog altijd toeneemt. Uit de resultaten van het onderzoek dat ik hier vanmiddag heb gepresenteerd, blijkt dat het niet demografische ontwikkelingen (de 'vergrijzing') of veranderingen in levenspatronen zijn die de oorzaak zijn 
van de stijging van het gebruik van medische voorzieningen, zoals huisarts, medisch specialist en fysiotherapeut. Het is eerder de verandering in de neiging om van deze medische voorzieningen gebruik te maken die de toename in het gebruik verklaren. Echter, hiermee is niet overtuigend aangetoond dat wij echt meer zorg nodig hebben. Doordat de kosten van het gebruik van medische voorzieningen niet in verhouding staan tot de waarde van dat gebruik, is het aannemelijk dat er sprake is van een zekere mate van overconsumptie van medische voorzieningen. Door deze vorm van 'moral hazard' kan uit gegevens over de feitelijke ontwikkeling van het gebruik van medische voorzieningen nooit conclusies worden getrokken over de waarde die wordt gehecht aan zorg. De waarde van zorg kan niet worden afgeleid uit de consumptie van zorg, maar moet op een andere manier worden bepaald. Ik heb vanmiddag een methode gepresenteerd die het mogelijk maakt om de waarde van zorg te bepalen. ${ }^{8}$

Voor een bepaald onderdeel van de gezondheidszorg - zorg voor hart- en vaatziekten - heb ik daarbij trachten aan te geven wat wij bereid zijn te betalen voor medische verrichtingen. Uit het onderzoek, waarvan ik hier de eerste resultaten heb gepresenteerd, blijkt dat de kosten van verrichten voor hart- en vaatziekten lager zijn dan de waar-

${ }^{8}$ In een verwant onderzoek kijken we niet naar de invloed van gezondheid op inkomen en welvaart, maar op de relatie tussen gezondheid en consumptieve bestedingen. Ook via de consumptie heeft gezondheid indirect een effect op welvaart. De eerste uitkomsten van dit onderzoek zijn gepresenteerd in de inaugurele rede van Maassen van den Brink (1998). 
de die wordt gehecht aan de eliminatie van het gezondheidsrisico's die hart- en vaatziekten met zich meebrengen. Het zou, naar mijn mening, goed zijn als in de komende jaren ook op andere onderdelen meer inzicht komt over de waarde die mensen hechten aan gezondheidszorg. Hiermee zou wellicht ook een maatschappelijke discussie kunnen worden gestart over de vraag hoeveel geld we over hebben voor de gezondheidszorg.

Zowel de vraag hoeveel we bereid zijn te betalen voor gezondheidszorg als de vraag of het gebruik van voorzieningen in de gezondheidszorg hoger is dan noodzakelijk, zijn vragen naar de doelmatigheid van de gezondheidszorg. Doelmatigheidsvraagstukken zijn bij uitstek het terrein waarop economen een bijdrage kunnen leveren. Gezien het maatschappelijk belang en de omvang van de gezondheidszorg is het opmerkelijk dat de beoefening van de gezondheidseconomie in ons land zo weinig aandacht krijgt. Ik hoop en verwacht in de komende jaren het gezondheidseconomisch onderzoek in Nederland een nieuwe stimulans te kunnen geven. Door deze oratie heeft $u$ een indruk kunnen krijgen van hetgeen $u$ van mij kunt verwachten.

Tot het begin van de jaren zestig was het op veel universiteiten in Nederland de gewoonte dat hoogleraren pas hun eerste salaris ontvingen nadat zij hun oratie hadden gehouden (Daalder 1997). Hieruit blijkt - in elk geval voor een econoom als ik - het grote belang dat werd gehecht aan het uitspreken van een oratie. Door de specialisatie in het onderzoek is de band tussen onderzoek en onderwijs losser geworden. De oratie is daardoor tegenwoordig bij uitstek de gelegenheid om in een openbaar college over onderzoek 
te doceren. Vanwege de nadruk op een openbare rede die voor een breed publiek toegankelijk is, is het ook bij uitstek de gelegenheid om de uitkomsten van gespecialiseerd onderzoek toegankelijk te maken voor een breed publiek. Om deze reden zou het naar mijn mening aanbeveling verdienen als hoogleraren niet alleen bij aanvaarding van hun ambt een openbare rede zouden uitspreken, maar dat zij dit geregeld zouden doen. Eens in de vijf jaar een oratie, waarbij de hoogleraar zijn of haar onderzoek presenteert aan een breder publiek, zou zeer stimulerend kunnen werken voor de betrokkenheid van de samenleving bij het universitaire onderzoek.

Tot slot zou ik graag enige woorden van dank willen richten aan diegenen die er toe hebben bijgedragen dat $\mathrm{ik}$ hier vandaag deze oratie heb mogen houden.

Geachte leden van het College van Bestuur, leden van het Faculteitsbestuur Gezondheidswetenschappen, leden van de Benoemingsadviescommissie, Hooggeleerde Maarse, beste Hans. U wil ik allen dank zeggen voor het in mij gestelde vertrouwen. Mijn benoeming is wellicht meer gebaseerd op vertrouwen dan de meeste andere benoemingen. Ik had immers tot mijn benoeming mijn sporen niet zozeer in de gezondheidseconomie, als wel in de arbeids- en onderwijseconomie verdiend. Ik geloof echter dat deze achtergrond vruchtbaar zal blijken te zijn voor mijn werk op het terrein van de gezondheidseconomie. Ik zal er alles aan doen om het in mij gestelde vertrouwen niet te beschamen. Een speciaal woord van dank wil ik richten aan de Hooggeleerde Maks. Beste Hans, zonder jouw telefoontje, nu ongeveer een jaar geleden, met de vraag of ik mijn curriculum vitae zou willen 
opsturen, zou ik hier vandaag niet hebben gestaan.

Hooggeleerde Maassen van den Brink, beste Henriëtte. Ooit werden wij door een journalist 'goudhaantjes' genoemd. Dat was nog voordat wij wisten hoe hoog wij nog zouden reiken. Relatief kort na elkaar zijn wij nu allebei hoogleraar geworden, jij in Wageningen en ik hier in Maastricht. Hoewel we beiden naar verschillende richtingen zijn uitgevlogen, heeft onze samenwerking er gelukkig niet onder te lijden gehad. Deze maand precies zeven jaar geleden begon onze intensieve samenwerking. Toen waren wij nog geen van beiden gepromoveerd. Zeven jaar later zijn wij niet alleen gepromoveerd, maar hebben we samen een groot aantal publikaties op onze naam staan, geven we leiding aan een grootschalig NWO Prioriteitprogramma en zijn we beiden benoemd tot hoogleraar. En dit is nog maar een kleine greep uit het succes van onze samenwerking. Ik geloof niet dat een van ons zeven jaar geleden had gedacht dat we samen zo succesvol zouden zijn. Evenals jij koester ik nog hoge verwachtingen over onze toekomst. Als 'goudhaantje' kan ik deze verwachtingen het beste onder woorden brengen met een gedicht over vogels:

\section{Verwachting}

Weet gij het ook de ganse nacht?

De vogels komen. Aan een geuren

- van wind, van water? - valt te speuren

hoe 't lage land een komst verwacht.

Mórgen het teken aan de lucht

- een frons, een lijn, een krimpend wolken -

en dan, bui van geluid, een vlucht 
die dalen gaat: de vogelvolken.

\begin{abstract}
En wéér staan in verwondering wij tussen dit gevleugeld sneeuwen; morgen - dan zijn wij, lieveling, het eerste paar van duizend eeuwen.
\end{abstract}

Ida Gerhardt (uit: Verzamelde Gedichten, Atheneum-Polak \& Van Gennep, Amsterdam, 1995)

Geachte leden van de Vakgroep Beleid, Economie en Organisatie van Zorg. Om de vogelvergelijking door te trekken: bij $U$ heb ik mij genesteld. $U$ heeft mij niet beschouwd als een koekoeksjong, maar mij het gevoel gegeven een genode gast te zijn. Hiervoor ben ik U dankbaar. Met $U$ zal ik er naar streven het gezondheidseconomisch onderzoek aan de Universiteit Maastricht nationaal en internationaal aanzien te geven.

Geachte leden van 'Scholar'. Hoewel ik U niet meer zo vaak zie als voorheen, is mijn betrokkenheid bij $U$ en Uw werk door mijn benoeming in Maastricht niet verminderd. Met $U$ hoop ik in de komende jaren te blijven werken om van 'Scholar' een nationaal en internationaal erkend centrum van onderzoek op het terrein van de relatie tussen onderwijs en arbeidsmarkt te maken.

Ter afsluiting wil ik $U$ nog één inzicht uit de economische wetenschap voorhouden. Dit keer niet uit de gezondheidseconomie, maar uit mijn andere liefde, de onderwijseconomie. Uit sociaal-wetenschappelijk onderzoek is bekend dat 
de maatschappelijke positie die men uiteindelijk bereikt voor een belangrijk deel wordt bepaald door het opleidings- en beroepsniveau van de moeder. Het is dan ook mijn moeder die ik als laatste wil bedanken: zonder haar inzet en opoffering had ik nooit zo ver kunnen komen. 


\section{Literatuur}

Adang, E. (1997), Medical technology assessment in surge$r y$, proefschrift Universiteit Maastricht

Akerlof, G. (1970), `The market of lemons: quality uncertainty and the market mechanism', Quarterly Journal of Economics 84, p. $488-500$

Arrow, K. (1963), 'Uncertainty and the welfare economics of medical care', American Economic Review 53, p. 941973

Borst-Eilers, E. (1997), 'Health policy in the Netherlands: A balance between containment and expansion', in: A. Schrijvers (ed.), Health and Health Care in the Netherlands, De Tijdstroom, Utrecht, p. 15-19

CBS (1994, Vijfennegentig jaar Statistiek in Tijdreeksen, 1989-1994, Centraal Bureau voor de Statistiek, Heerlen/Voorburg

CBS (1997), Statistisch Jaarboek 1997, Centraal Bureau voor de Statistiek, Heerlen/Voorburg

Daalder, H. (1997), Universitair Panopticum: herinneringen van een gewoon hoogleraar, Arbeiderspers, Amsterdam

Ginneken, J. van, Bannenberg, A. \& Dissevelt, A. (1989), Gezondheidsverlies ten gevolge van een aantal belangrijke 
ziektecategorieën in 1981-1985, NIPG/TNO/CBS, 1989

Gray, B. (1986) (ed.), For-profit enterprise in health care, National Academy of Science Press, Washington

Groot, W. (1998), 'An empirical analysis of the use of health care services', mimeo Maastricht University

Groot, W., Maassen van den Brink, H \& Plug, E. (1998), 'Calculating the value of life by an income evaluation approach', mimeo Maastricht University/University of Amsterdam

Kapteyn, A. \& Praag, B.M.S. van (1973), 'Further evidence on the individual welfare function of income: an empirical study in the Netherlands', European Economic Review 4, p. 33-62

Kosa, J. \& Robertson, L. (1975), 'The social aspects of health and illness', in: Kosa, J. \& Zola, I. (eds.), Poverty and Health: a sociological analysis, Harvard University Press, Cambridge MA

Maassen van den Brink, H. (1998), Alles is Economie, Inaugurele Rede, Landbouwuniversiteit Wageningen

Newhouse, J. (1992), 'Medical care costs: how much welfare loss, Journal of Economic Perspectives 6, p. 3-21

Newhouse, J. (1996), 'Reimbursing health plans and health providers: efficiency in production versus selection', Journal of Economic Literature 34, p. 1236-1263 
Pauly, M. (1987), 'Nonprofit firms in medical markets', American Economic Review 77, Papers and Proceedings, p. 257-262

Phelps, C. (1992), 'Diffusion of information in medical care', Journal of Economic Perspectives 6, p. 23-42

Praag, B. M. S. van (1968), Individual Welfare Functions and Consumer Behavior, North-Holland, Amsterdam

Stano, M. (1987), 'A clarification of theories and evidence on supplier-induced demand for physician services', Journal of Human Resources 22, p. 501-520

Weisbrod, B. (1991), 'The health care quadrilemma: an essay on technological change, insurance, quality of care, and cost containment', Journal of Economic Literature 29, p. $523-552$

WRR (1997), Volksgezondheidszorg, Wetenschappelijke Raad voor het Regeringsbeleid, Sdu Uitgevers, Den Haag 